\title{
Solar powered rotorcraft: a multidisciplinary engineering challenge for undergraduate students
}

\section{Aaron Danner, Martin Henz, Brian Shohei Teo}

Aaron J. Danner, Martin Henz, Brian Shohei Teo, "Solar powered rotorcraft: a multidisciplinary engineering challenge for undergraduate students," Proc.

SPIE 10452, 14th Conference on Education and Training in Optics and Photonics: ETOP 2017, 104520J (16 August 2017); doi: 10.1117/12.2266484

SPIE Event: 14th Conference on Education and Training in Optics and Photonics, ETOP 2017, 2017, Hangzhou, China 
Invited Paper

\title{
Solar powered rotorcraft: a multidisciplinary engineering challenge for undergraduate students
}

\author{
Aaron J. Danner*, Martin Henz, Brian Shohei Teo \\ National University of Singapore, 21 Lower Kent Ridge Road, 119077, Singapore \\ *adanner@,nus.edu.sg
}

\begin{abstract}
Controlled, fully solar-powered flight in a rotorcraft is a difficult engineering challenge. Over the past five years, multidiciplinary teams of undergraduate engineering students at the National University of Singapore have built and test-flown a succession of increasingly impressive and larger, more efficient aircraft. While many other multidisciplinary or purely photonics projects are available to students in our programme, this particular project attracts an unusual level of excitement and devotion among students working on it. Why is that the case, and what, in general, makes a good final year undergraduate design project? These questions will be explored. Additionally, videos of solar helicopter test flights and spectacular crashes will be shown in the presentation for which the proceedings below have been prepared.
\end{abstract}

Keywords: Curriculum development, multidisciplinary education, solar powered aircraft

\section{INTRODUCTION}

The Department of Electrical and Computer Engineering at the National University of Singapore has a feature which is common to many engineering undergraduate programmes around the world, namely, a final year capstone project in which students spend two semesters, or one academic year, on a major engineering project. Such projects include both design-oriented and research-oriented endeavors; each project is mentored by a faculty member. Students can propose their own projects or select from a list of projects that have been proposed by professors. Most students choose the latter route. Enrollment in our 2015 department cohort was 235 students, similar to the enrollment in other recent years, which is a number sizeable enough to necessitate a procedure for matching student to project. The procedure operates as follows: First, professors use a web-based platform to propose multiple projects which students can view and choose. Second, after a period of time, students who have nearly completed their third year must each submit eight possible ranked project choices prior to enrollment in their final year. Students are not aware of each others' choices or whether the project that they would like to be involved in has already been taken up by another student. Students can see the name of the professor who would be the supervisor of each project. Our department had 82 faculty members who proposed projects in 2015. Naturally, certain popular projects may have multiple students bid on them ("oversubscription"); certain professors may have all of their proposed projects attracting bids by students, whereas others have very few. A semi-manual matching process is carried out to ensure that the best possible match of student-to-project occurs, with professorial teaching load taken into consideration for balancing along with the students' ranked choices and the students' backgrounds or grades in prior years to serve as tie breakers, among other factors. Anecdotally, certain professors or areas of study are much more popular than

14th Conference on Education and Training in Optics and Photonics: ETOP 2017, edited by Xu Liu,

Xi-Cheng Zhang, Proc. of SPIE Vol. 10452, 104520J · @ 2017 ICO, IEEE, OSA, SPIE

CCC code: $0277-786 \mathrm{X} / 17 / \$ 18 \cdot$ doi: $10.1117 / 12.2266484$

Proc. of SPIE Vol. 10452 104520J-1 
others from year to year. In this letter, we attempt to measure such popularity, and then look at some specific project examples.

\section{POPULARITY OF SENIOR YEAR PROJECTS}

We first look at each project by area of study, to see which areas are oversubscribed (that is, we have more students than available projects in those areas), with results shown in Figure 1 by project (left) and by professor (right). When measuring popularity of projects, only the students' first choices are considered. In 2011 and 2012, Control Intelligent Systems and Robotics ("Robotics") and Integrated Circuits and Embedded Systems ("ICs") were both oversubscribed, and in 2014 Power and Energy Systems ("Energy") was oversubscribed, as seen in Figure 1 (left) with a ratio greater than 1 . Other areas were less popular. Is this due to simply having fewer projects to choose from in the "popular" areas of study? We control for this by also considering project selections per professor in each area. Again, Robotics, ICs, and Energy attracted the most student selections. In 2014, for example, Energy projects attracted 6.71 first-choice selections from students for each professor proposing projects. With equal teaching load in that year, each professor should theoretically mentor 3.27 students each, representing a huge oversubscription for that area, that year. Why do certain projects attract the attention of students more than others? In the next section, we look at certain projects in detail.

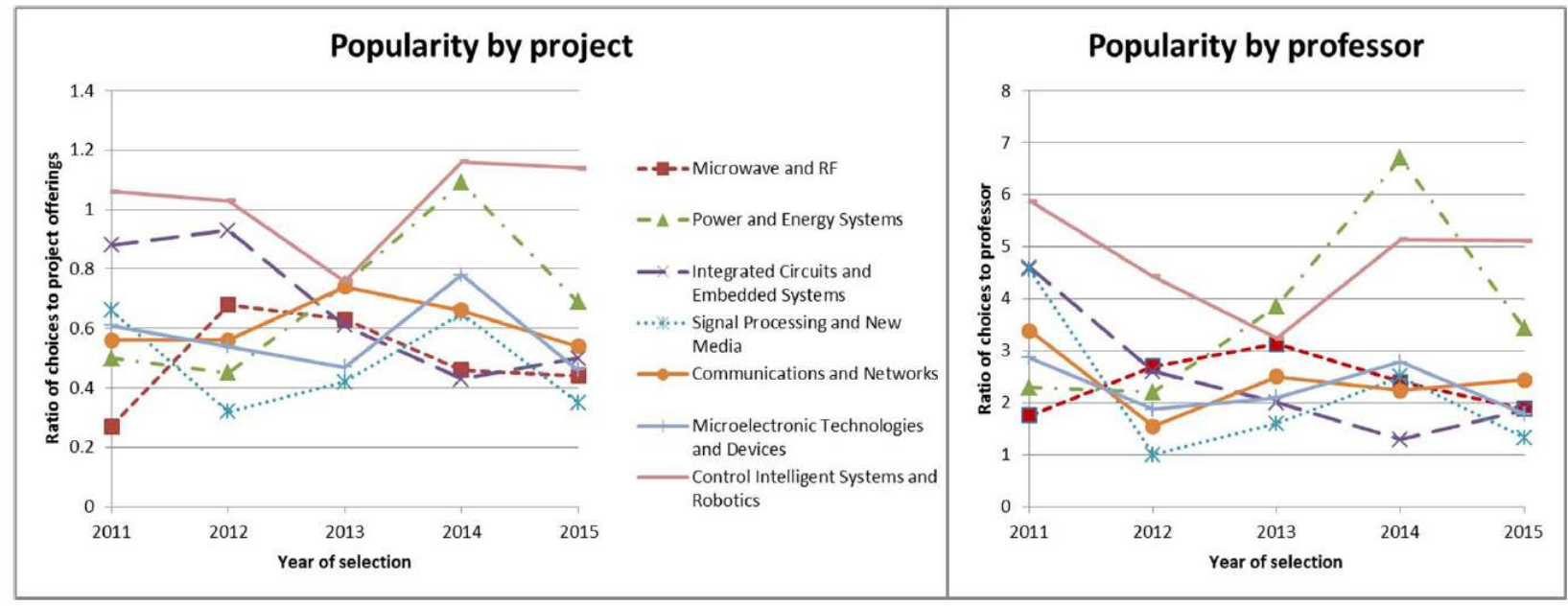

Figure 1: Popularity by project shows, year-on-year, the ratio of first-choice student selections to the number of projects offered in each area of study. Popularity by professor shows, year-on-year, the ratio of first-choice student selections to the number of professors offering projects in each area of study.

\section{SPECIFIC EXAMPLES}

Table 1 shows projects proposed by one faculty member from 2011-2015. The projects that attracted the greatest interest are those involving robotics and solar energy, consistent with the results in Figure 1. However, something interesting emerges which was subjectively consistent when looking at projects generally available to each cohort. Projects which have titles understandable to the layman, or projects involving building something tangible tended to attract greater interest. Projects involving only "modeling and simulation" or projects with unclear, boring goals ("reducing absorption") tended to have no or low numbers of bids from students. It's not surprising that student performance eventually correlates with how motivated a student initially is to start a year-long project. 
The most popular engineering project in 2014 in the department, measured by the number of first-choice selections, was the NUS Solar-Powered Aerial Vehicle Team. In other years this project has consistently proven to be among the most popular first-bid project in the department. It integrates multiple aspects of engineering creativity, design, and aims toward a record-setting goal. In the next section we describe this project, and the goals and achievements of the students.

Table 1: Projects proposed by Assoc. Prof. Aaron Danner, 2011-2015

\begin{tabular}{|l|l|l|}
\hline $\begin{array}{l}\text { Year } \\
\text { Offered }\end{array}$ & Proposal Title & $\begin{array}{l}\text { Number of first-choice } \\
\text { selections }\end{array}$ \\
\hline 2011 & Remote-controlled solar powered robot & 7 \\
\hline 2011 & $\begin{array}{l}\text { Modeling and simulation of optical materials for solar } \\
\text { energy applications }\end{array}$ & 0 \\
\hline 2011 & $\begin{array}{l}\text { An integrated spectacles-based blue LED light therapy } \\
\text { device for a clinical trial }\end{array}$ & 2 \\
\hline 2011 & $\begin{array}{l}\text { Design of a short range high data rate communications } \\
\text { system with lasers }\end{array}$ & 1 \\
\hline 2011 & Outdoor testing of solar cells/panels & 2 \\
\hline 2012 & Indoor solar powered robot & 6 \\
\hline 2012 & Low power solar module controllers & 3 \\
\hline 2012 & Solar powered aerial vehicle & 6 \\
\hline 2012 & High speed modulation of optoelectronic devices & 0 \\
\hline 2012 & Reducing absorption in optical modulators & 0 \\
\hline 2013 & Solar-powered aerial vehicle team & 4 \\
\hline 2013 & Indoor solar-powered robot team & 4 \\
\hline 2013 & Singapore Tech Factor Challenge & 2 \\
\hline 2014 & NUS Solar-Powered Aerial Vehicle Team & 6 \\
\hline
\end{tabular}

\section{THE NUS SOLAR POWERED HELICOPTER}

Beginning in 2011, a group of 2-3 students in each academic year have set out to create the world's first controlled vertical-takeoff-and-landing solar vehicle. Even in 2017, this aviation feat has not yet been accomplished. A notable attempt at the University of Maryland [1] in 2016 achieved liftoff, however, the aircraft was airborne for only a few seconds and flight was uncontrolled. The UM designed employed large, slowly rotating airfoils to achieve greater aerodynamic efficiency at the expense of control. The goal of the NUS project is fully controlled stable flight - under full sunlight and hovering stably outside of ground effect, the NUS team has achieved $60 \%$ solar ( $40 \%$ battery) with the 48-cell version of the aircraft in Figure 2. 


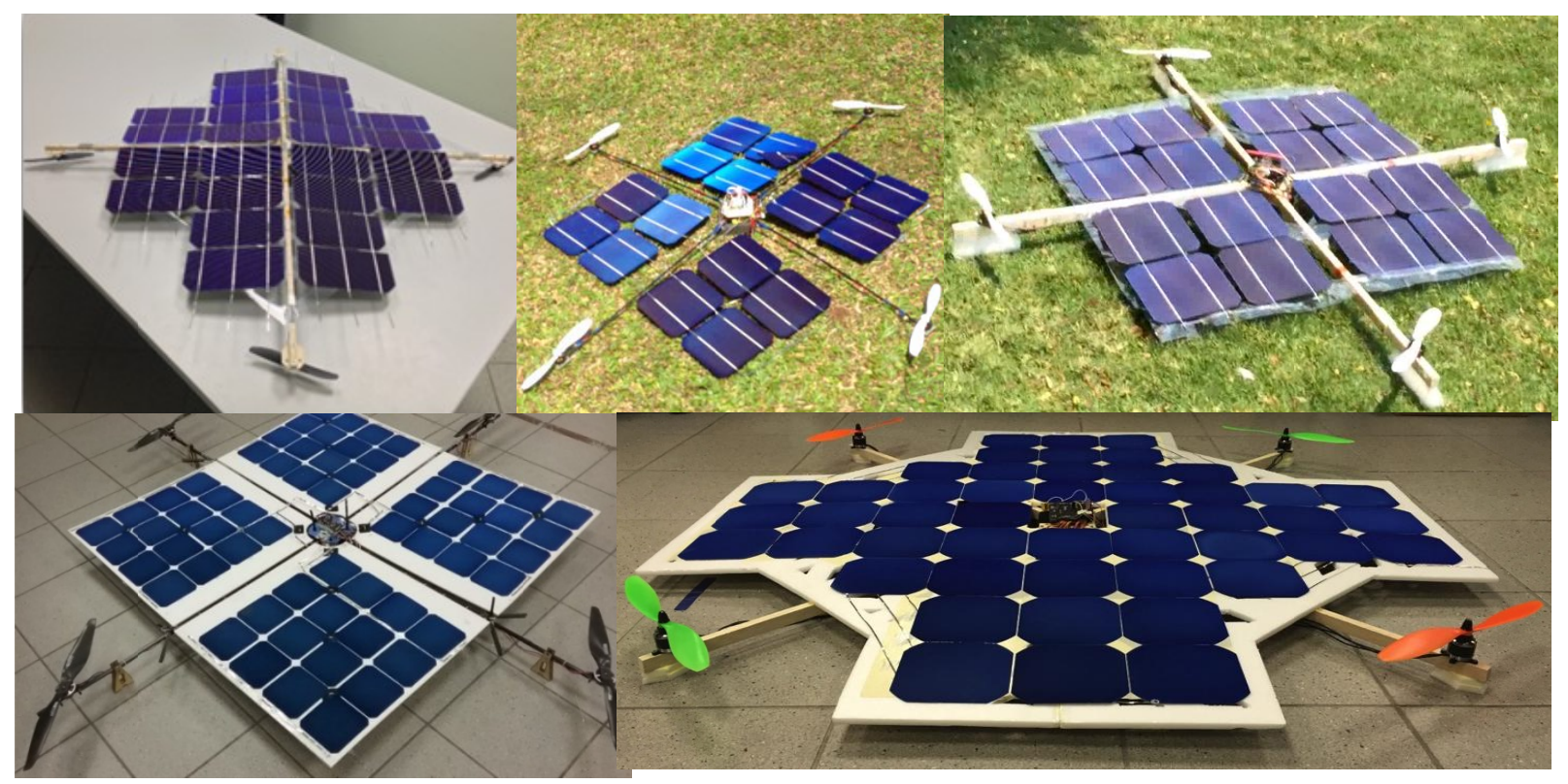

Figure 2: Iterations of the solar aerial vehicle (clockwise from top left) by completion date: 2012 (12 cells), 2013 (16 cells), 2014 (16 cells), 2015 (48 cells), 2016 (64 cells).

The project involves multidisiplinary design skills, touching on computing/control, mechanical engineering (frame design, motor selection), wireless technology, solar cell integration and maximum power point tracking, power systems design, and engineering project management and teamwork. Although a challenging project, students are highly motivated. Attempting a world-record goal stated in clear and simple terms, working in a motivated and interdisciplinary team of fellow students, working with a project that can be easily understood to non-technical people, and having tools available to make meaningful progress are all hallmarks of a sought-after "popular" final year project. Starting in 2016-2017, we have moved this project to the "Design Centric Curriculum", where students from various engineering disciplines can work together on an engineering project.

\section{ACKNOWLEDGMENTS}

Funding from NUS's Electrical and Computer Engineering Department, the Design Centric Programme, and NUS CDTL (Centre for Development of Teaching and Learning) is acknowledged. Students contributing to the project are as follows: Nazir Kamaldin, Eugene Chan, Congyi Tan, Ian Teh, Jin Shajiang, Xu Jinzhou, Heng Zh Wei, Xu Yang, Yeo Jun Han, Goh Chong Swee, and Kuan Jun Ren. Prof. Koen Mouthaan's help in supervising the first groups of students is most appreciated. Assistance from NUS's Solar Energy Research Institute (SERIS) and Prof. Armin Aberle in testing solar cells is also acknowledged.

\section{REFERENCES}

[1] The "Gamera Solar-Powered Helicopter" (September 2016) available online: http://www.umdrightnow.umd.edu/news/university-maryland-achieves-first-flight-solar-powered-pilotedhelicopter 